\title{
Marine Transportation in the Philippines:
}

\section{The Maritime Accidents and their Causes}

\author{
† Orlando S. Dimailig $\cdot$ Jae-Yong Jeong* $\cdot$ Chol-Seung Kim** \\ ${ }^{\dagger}, *, * *$ Professors, Marine Transportation Division, \\ Mokpo National Maritime University \\ 571 Chukkyo-dong, Mokpo, 530-729, Korea
}

Abstract : This paper details the maritime accidents that occurred in the Philippines from 1972 to 2010. Firstly, it describes the general maritime situation in the country. It was followed by the traffic and safety infrastructure and the prevailing weather in the archipelago. The third section deals with the accidents' statistics and their geographical locations which is further sub-divided into three regions. It is grouped according to 10-year period. This paper describes the actual maritime situations, the pertinent national regulations, the inter-agencies policies and their safety regimes. It illustrates the shipping environment in the country including the maritime aids and infrastructure and the on human element factors.

Key words : Maritime Transportation, maritime accidents, maritime agencies, capsized, ships groundings, collisions, human element, STCW 78 Code, VTMS, Nautical Highway.

\section{Introduction}

The Philippines is an archipelago of approximately 7,107 islands and the shipping transport industry plays a very vital role in the country's growth and development. The country's archipelagic setting requires an efficient maritime transport infrastructure composed of serviceable ports, marine traffic safety aids, and systems. The country's domestic shipping industry, however, has been regarded as inefficient. This is rather unfortunate as the industry has a large number of shipping companies where competition could be expected to be a powerful force for eliminating inefficiency and vast pool experienced merchant marine officers and crews who rather went out to ply the foreign international fleet than serve the domestic waters.

This paper aims to illustrate the present realistic maritime situation in the country. It describes the accidents, their types and the locations where these tragedies mostly occurred. The causes of these accidents were, then, analyzed and recommendations presented.

\section{Marine transportation situation}

\subsection{Maritime government agencies}

The Department of Transportation and Communication
(DOTC) is the main government agency in-charge of the maritime transport. Its attached agencies are the Maritime Industry Authority (MARINA) which is mandated to integrate the development, promotion and regulation of the country's maritime industry ${ }^{[6]}$; the Philippine Coast Guard (PCG) is responsible for the promotion of safety of life and property at sea, safeguard the marine environment and resources and enforce all applicable maritime laws; and the Philippine Ports Authority (PPA) whose responsibility as developer, operator, maintainer and regulator of all the ports under its jurisdiction. ${ }^{[13]}$ The Philippine Atmospheric, Geophysical \& Astronomical Services Administration (PAGASA), while under a different government agency, gives information and advisory for the prevailing weather conditions and forecasts. ${ }^{[7]}$ The Office of Transport Security (OTS) is the single authority for all modes of transportation security in the Philippines per ICAO and IM0 guidelines. OTS organized the Maritime Transportation Security Bureau (MTSB) to attend to the maritime concerns. ${ }^{[1]}$ Fig. 1 illustrates the hierarchical organization of maritime related agencies.

\footnotetext{
† First and corresponding author, osd@mmu.ac.kr, dimailig_82@yahoo.com 010)4991-2013

* jyjong@mmu.ac.kr 010)4547-4240

** cskimu@mmu,ac.kr 010)2984-0396

Note) This paper was presented at the Asia Navigation Conference 2010, Proceedings, Incheon, Korea. (November 4-6, 2010 pp. 151-160) with the same subject title "Marine Transportation in the Philippines: The Maritime Accidents and their Causes". It was edited for compliance to the requirements of KINPR.
} 


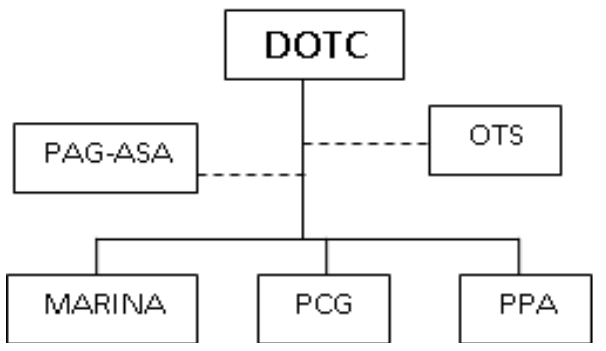

Fig. 1. Maritime related organizational structure

\subsection{Ship calls statistics}

According to the PPA Annual Report 2009, ${ }^{[13]}$ the country has approximately 950 ports and landing stages all over the country. Most of these ports and landing stages are privately owned and maintained, and only a few are public ports. However, port facilities in the country are far below world-class standards, with some ports still under-developed.

Table 1 shows the number of ships calling at the different ports in the country culled from the PPA data of 2009. It shows a total of 314,430 calls, of which 304,652 were domestic trade and only about 3\% of foreign ships visited the local ports. Other ports are operated by different agency aside from PPA and, thus, not illustrated herein.

Table 1 Number of Ship-calls. $(2009)^{[13]}$

\begin{tabular}{|c|c|c|c|}
\hline \multicolumn{4}{|c|}{$\begin{array}{c}\text { NUMBER OF SHIPCALLS } \\
\text { PORT STATISTICS 2009 PPA DATA (At Berth }\end{array}$} \\
\hline \multirow{2}{*}{ PDO/PMO } & \multicolumn{3}{|c|}{ SHIPCALLS } \\
\hline & Total & Domestic & Foreign \\
\hline PDO MANILANNORLUZ & 22,341 & 17,368 & 4,973 \\
\hline Manila - N. Harbor & 5,043 & 4,602 & 441 \\
\hline Manila - S. Harbor & 7.650 & 5.822 & 1.828 \\
\hline$-M .1 . C . T$ & 2,042 & 105 & 1,937 \\
\hline Limay & 6,924 & 6.435 & 489 \\
\hline San Fernando & 682 & 404 & 278 \\
\hline PDO SOUTHERN LUZON & 88,179 & 86,817 & 1,362 \\
\hline Batangas & 40,331 & 39,264 & 1,067 \\
\hline Calapan & 22,133 & 22,133 & 0 \\
\hline Logazpi & 20.617 & 20.547 & 70 \\
\hline Puerto Pnincesa & 5,098 & 4,873 & 225 \\
\hline PDO VISAYAS & 117,195 & 116,697 & 498 \\
\hline Dumaguete & 34,937 & 34,892 & 45 \\
\hline llovilo & 19.266 & 19.140 & 126 \\
\hline Omoo & 12,082 & 11.900 & 182 \\
\hline Pulupandan & 24,009 & 23,938 & 71 \\
\hline Tacioban & 8,422 & 8,364 & 58 \\
\hline Tagbilaran & 18,479 & 18.463 & 16 \\
\hline PDO NORTHERN MIND. & 48,875 & 48,123 & 752 \\
\hline Cagayan de Oro & 12,542 & 12,175 & 367 \\
\hline Migan & 14.296 & 14.186 & 110 \\
\hline Nasipit & 1,103 & 1,076 & 27 \\
\hline Ozamiz & 13,659 & 13,650 & 9 \\
\hline Surigao & 7,275 & 7,036 & 239 \\
\hline PDO SOUTHERN MIND. & 37,840 & 35,647 & 2,193 \\
\hline Cotabato & 461 & 461 & 0 \\
\hline Dapitarn & 2,640 & 2,617 & 23 \\
\hline Davao & 22,234 & 20,546 & 1,688 \\
\hline General Santos & 1.504 & 1.107 & 397 \\
\hline Zamboange & 11,001 & 10,916 & 86 \\
\hline TOTAL & 314,430 & 304,652 & 9,778 \\
\hline
\end{tabular}

\subsection{Shipping traffic routes}

Fig. 2 shows the traditional routes plied by domestic ships. The red dotted lines connect the main ports in the country with the other ports which are concentrated mostly between the small island-ports in the southern part of the country.

The Ro-Ro mode of service was introduced by the government under its policy of "Nautical Highway" which main goal is to abridge the archipelago through shipping transport. This service connects the main island of Luzon to the southern provinces, thereby, easing the burden of merchants in transporting their goods from the south to the northern markets and vice- ${ }^{-}$ersa.

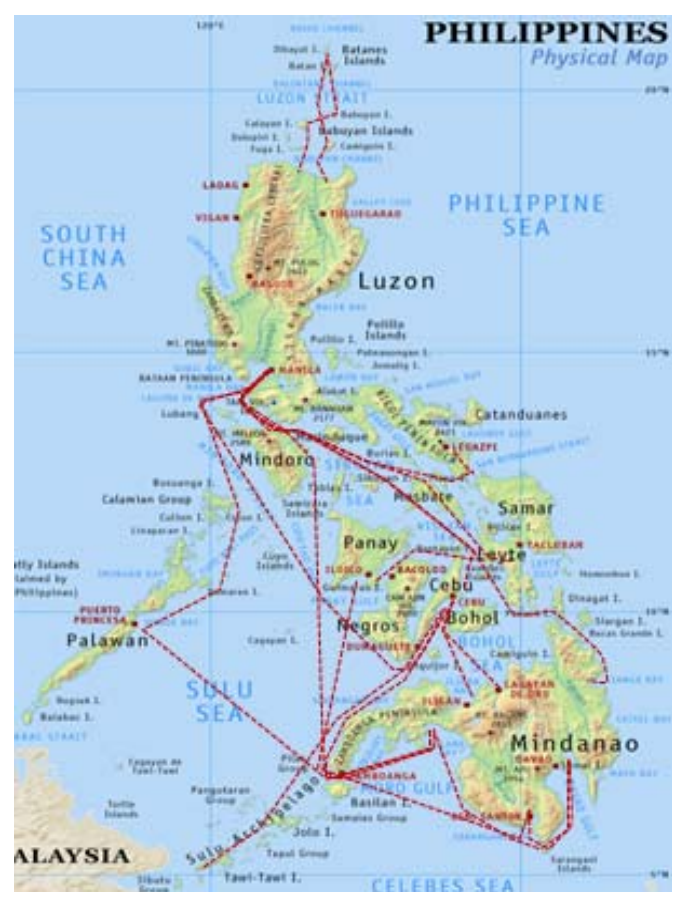

Fig. 2. Domestic shipping routes

\subsection{The maritime traffic and safety infrastructure}

\subsubsection{Navigational aids}

According to a JICA study, the country needs at least 700 lighthouses to illuminate the country's major waterways. From the list of PCG-maintained light-stations (Table 2), there are only 549 with 97 non-operational: deactivated or under-construction. ${ }^{[9]}$ This only achieves the minimum safety standards required and not the ideal number of these $\mathrm{so}^{-}$called nav-aids. Meanwhile, the PPA has the nominal responsibility for dredging the ports' waterways, but it has barely kept up with dredging activities for harbors and their approaches. 
Table 2. Philippine Light-stations ${ }^{[9]}$

PHILIPPINE LIGHTSTATIONS
\begin{tabular}{|c|l|c|c|}
\hline No. & \multicolumn{1}{|c|}{ Location } & TTL & N/0 \\
\hline 1 & NORTHERN LUZON & 42 & 7 \\
\hline 2 & $\begin{array}{l}\text { NATIONAL CAPITAL REGION- } \\
\text { CENTRAL LUZON }\end{array}$ & 37 & 5 \\
\hline 3 & SOUTHERN TAGALOG & 103 & 7 \\
\hline 4 & PALAWAN & 34 & 3 \\
\hline 5 & BICOL & 70 & 12 \\
\hline 6 & CENTRAL VISAYAS & 125 & 13 \\
\hline 7 & WESTERN VISAYAS & 49 & 20 \\
\hline 8 & NORTHERN MINDANAO & 60 & 19 \\
\hline 9 & SOUTHWESTERN MINDANAO & 29 & 11 \\
\hline
\end{tabular}

\subsubsection{Vessel traffic management system}

PPA has established two technologically-advanced, 24/7, vessel monitoring systems. These vessel traffic systems (VTMS) were installed at the ports of Manila (North Harbor) and Batangas Port ${ }^{[12]}$. Ship's Routeing System was also established at the north and south channels of Corregidor Island. Despite occasional technical and operational setback, distressed vessels are given back-up support in times of emergency, piracy, and during typhoons and other form of calamities. TSSs were established at the entrance to Manila Bay north and south passages of Corregidor Island $^{[8]}$. Interviewed VTMS operators disclosed that the recommended routes were not followed ${ }^{[4]}$. TSS recommended routeing was also placed at the southern waterways of Cebu City. All the TSS are not IMO sanctioned.

\subsubsection{The prevailing weather}

Fig. 3 tracks the tropical cyclones that entered the

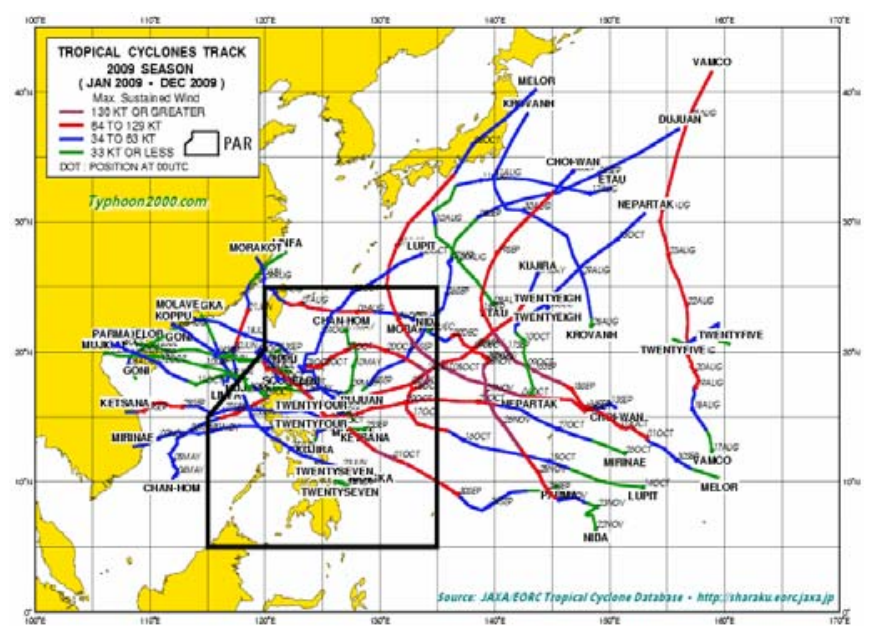

Fig. 3. Tropical cyclone track - 2009 season (Jan-Dec 2009) ${ }^{[14]}$
Philippine area of responsibility (in bold black line) and the typhoons that crossed the archipelago in 2009. According to PAGASA, there are approximately 20 storms of different strengths that enter the Philippines annually. Results of BMI investigation of mostly the sinking and grounding incidents were due to bad weather.

\section{The maritime accidents and their causes}

There had been a spate of major maritime incidents that occurred in the Philippines and claimed thousands of lives. Most of these sea disasters had been dubbed as the worst in maritime history in peacetime. The damages to the environment have been somewhat down-played due to the enormity of the lives lost and the porous setting of the islands dissipated the ecological damages caused by spilt or leaked oil and chemicals. Millions of Filipinos, many of them too poor to afford air travel, use the seas and waterways to travel between islands, on everything from fast steel-hulled ferries to wooden motorized dugouts with outriggers (Figs 4).
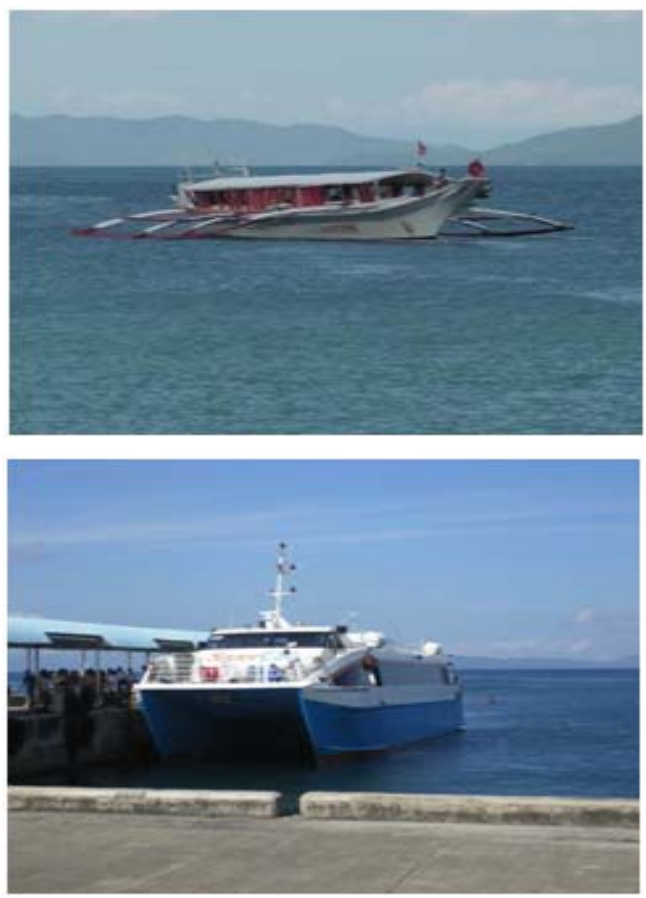

Fig. 4 Motorized banca with outriggers and Super-cat steel-hulled ferry

\section{1 Maritime accidents ${ }^{(3)(9)(10)}$}

Accidents data were taken from PCG and MARINA that occurred in the whole archipelago from 1972 until the present. Recent information was taken from the Lloyds 
MUI list of casualties and online news and print articles. These data were gathered and compiled together and formed part of this paper. Fig. 5 shows the different types of accidents and these were grouped into different scenarios. This paper discusses only three types of accidents: Collisions, Capsized and Grounding.

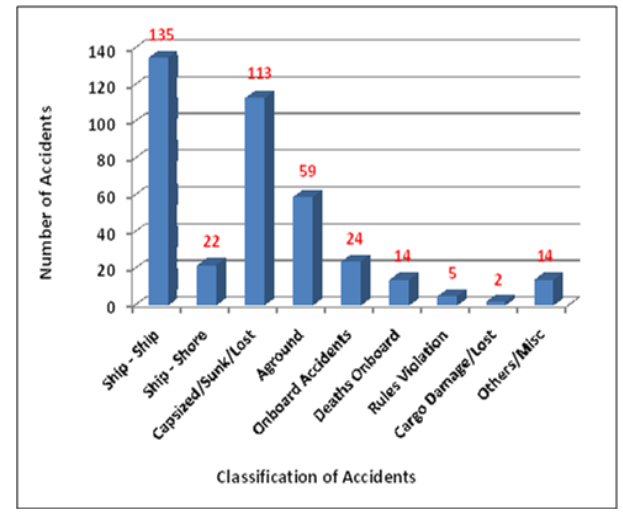

Fig. 5 Types of accidents (1972 to 2010)

Other accidents reported as "Ship-shore" (22) involved ships in contact with shore facilities: bumping wharf, damage to wharf or fenders, damage to pier, damage to dolphin, hitting shore facilities struck the sea wall, ramming wharves, etc. "Onboard accidents" (24) involved those internal accidents like engine explosion, engine trouble, explosion, fire onboard; while "Deaths Onboard" (14) were those that fell overboard, one swiped by line overboard and those classified as plain death on board; "Rules Violations" (5) involved those reported misconduct and COLREGS violation; "Cargo Damage/Lost" only 2 of the reported jettisoned cargos and damage to cargos; and those accidents classified under "Others/Misc." were: broke from tow, dragged/drifted, snapping anchor chain and other not identified and were only given their corresponding BMI coded numbers.

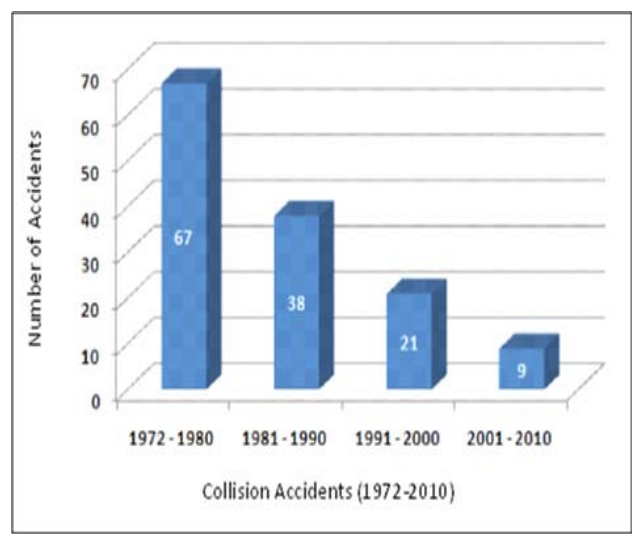

Fig. 6 Collision accidents (1972-2010)
"Ship-ship" accidents (135) were those accidents with contacts between ships. Official reports on these accidents classified them as: Collisions, allusions, ramming, bumping and hitting. These were all compiled under "Collisions accidents" shown by Fig. 6. The graph in Fig. 5 shows that of all reported accidents, the 'Ship-Ship' topped the scale which was attributed to poor navigation, non-observance of the rules of the road and lack of prudent seamanship.

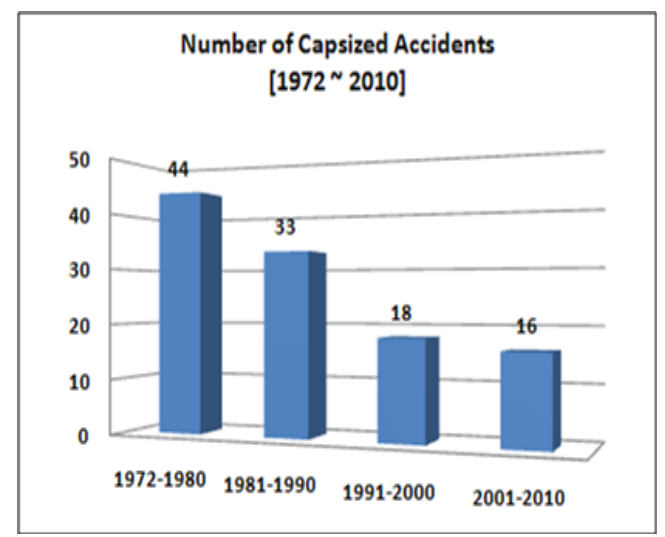

Fig. 7 Capsized accidents (1972-2010)

Capsized/Sunk/Lost (113) in Fig 5 are those that were reported as sinking, loss, capsizing, etc. in the official record of PCG and MARINA and is described here as "Capsized accidents" shown in Fig. 7. In the graph it can be readily observed that this accident has continuously $\mathrm{de}^{-}$ creased since 1972.

However, in terms of the number of fatalities, the accidents in the years 1980s until 2000s were the most horrendous. Data collected from various sources differ from the official recorded data of the number of casualties (dead and/or missing) because most of the ships lost and/or capsized were overloaded or passengers were poorly manifested.

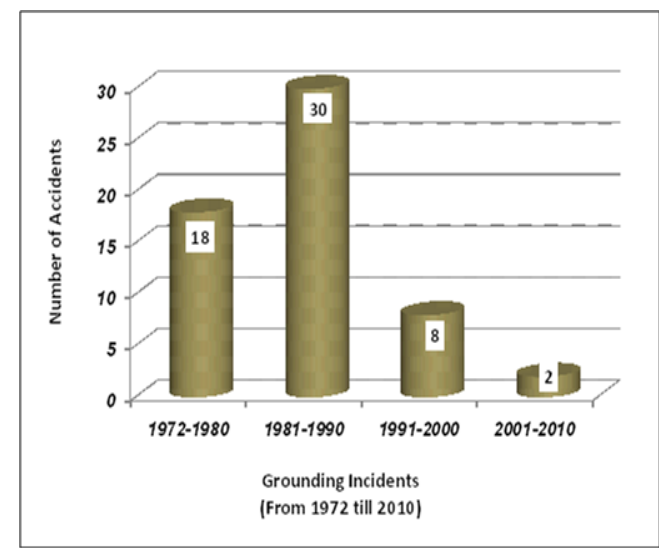

Fig. 8. Grounding accidents (1972-2010) 
Orlando S. Dimailig $\cdot$ Jae-Yong Jeong $\cdot$ Chol-Seung Kim

In Fig. 8 graphs the "Grounding" accidents (59) and were classified, in the official record, as 'grounding', 'hit a rock', 'hitting submerged object', 'submerged' and there is one reported as 'intentional beaching'.

The 'Capsized' and 'Grounding' accidents (1972-2010) were reportedly mostly caused by bad weather. One shipping company whose ships were involved in major catastrophes that claimed so many lives publicly blamed the weather bureau, Philippine Atmospheric, Geophysical and Astronomical Services Administration (PAGASA), for gross negligence, saying that inaccuracies in its weather forecasts caused its ships to find itself in the eye of the storm, leading to their sinking.

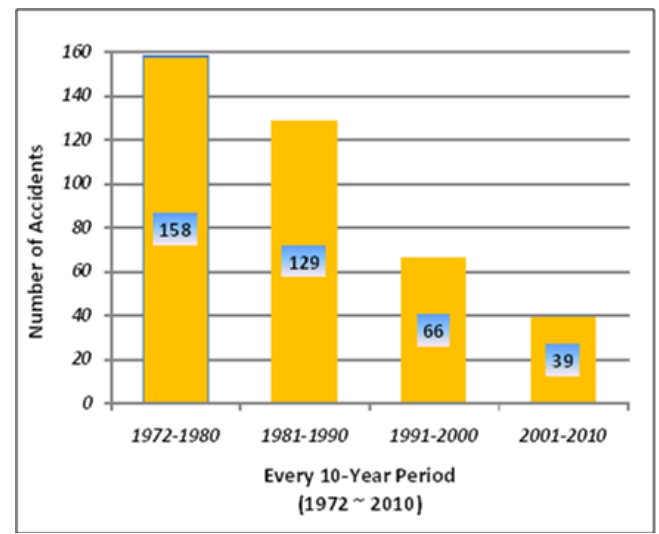

Fig. 9 Accidents grouped in 10-Year period $(1972$ - 2010)

The list of accidents was grouped according to ten-year periods as shown above by Fig 9 . It can be observed that the numbers were declining, through the years, however, it cannot be safely assumed that progress has been attained in minimizing their occurrence.

\subsection{Notable maritime tragedies ${ }^{(3)(9)(10)}$}

Table 3 lists some of the notable maritime accidents that occurred in the country from 1987-2010 according to the data from PCG, MARINA and news accounts.

\subsection{Maritime accident's geographical locations ${ }^{(9)}$}

The locations of accidents were sub-divided into three regions - Northern and Central Luzon, NCR (National Capital Region - Manila and adjacent cities) and Southern Tagalog regions, and the Mindanao region.

The maritime accident's geographical locations were grouped by latitudes as shown in Fig. 10. This covers the whole archipelago from the northernmost territories of Amianan islands $\left(21^{\mathrm{O}} 45^{\prime} \mathrm{N}, 121^{\mathrm{O}} 56^{\prime} \mathrm{E}\right)$ down to Tawi-tawi islands $\left(04^{\mathrm{O}} 48^{\prime} \mathrm{N}, 119^{\circ} 50^{\prime} \mathrm{E}\right)$ in the southern tip of the
Table 3 Notable maritime accident from 1987-2010

Doña Paz (1987.12.20) Collided/Sunk with M/T Vector. 1,800 died, but 4,341 persons were allegedly killed.

Dona Marilyn (1988.10). Ferry sunk, more than 250 dead.

Cebu City (1994.12). Collided with a cargo ship, about 140 dead.

Princess of the Orient (1998.09.18) Ferry sank in typhoon. About 150 died. Survivor waited for $12 \mathrm{H}$ to be rescued.

Annahanda (2000.04) Overloaded/Sunk. About 100 people died.

Superferry-12 (2003.05.25) Collision with MV San Nicholas. 43

dead and 21 missing.

Superferry-14 (2004.02.27) Bombed/Terrorism, 116 dead.

Solar I (2006.08.11) Sunk in bad weather. 190,000 liters of oil spilled.

Princess of the Stars (2008.06.21) Sunk in typhoon. 700-800 passengers and about 300 crews died/missing.

Don Dexter Kathleen (2008.11) Small wooden-hulled ferry sunk in freak winds leaving 42 dead.

Maejan (2008.12) Ferry capsized, leaving 30 dead.

Commander-6 (2009.06) Wooden-hulled motorized banca had cracked open and sunk, leaving 12 dead.

Superferry-9 (2009.9.6) Tilted sharply and sunk. 9 killed

Catalyn B (2009.12.24) Wooden-hulled motorized banca collided with Fishing boat. 4 died, 23 still missing.

Baleno-9 (2009.12.26) Ferry sunk due flooding. 3 died and at least 22 others were still missing.

Gold Trans 306 (2010.07.14) Barge aground during the typhoon, part of its coal cargo lost overboard.

West Ocean 1 (2010.07.20) caught fire following an explosion on board.

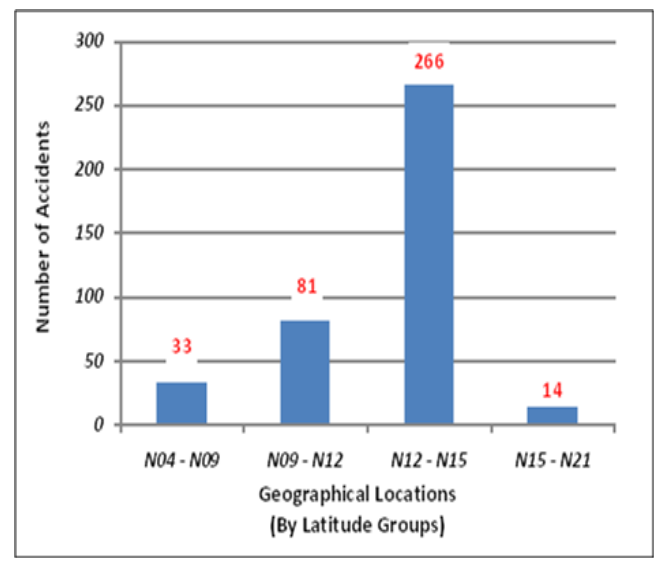

Fig. 10 Accidents grouped by latitudes

Philippine archipelago. Fig. 10, also, shows that the latitudes N12-N15 degrees, where the NCR and the Southern Tagalog region are located, have the most occurrence of accidents.

The figures below, meanwhile, show the general locations of the maritime accidents superimposed on $\mathrm{ARC}^{\prime} \mathrm{s}$ charts and were plotted as red dots. Fig. 11 shows the accidents along the coast of Lingayen Gulf , Cagayan River 
and the Babuyan Island in the northern parts of the country.

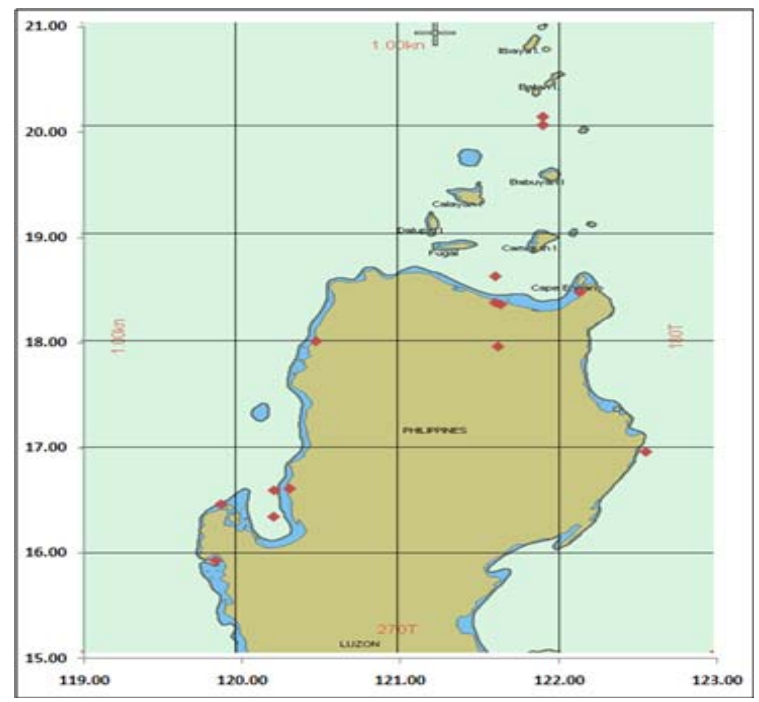

Fig. 11 Central and Northern Luzon area

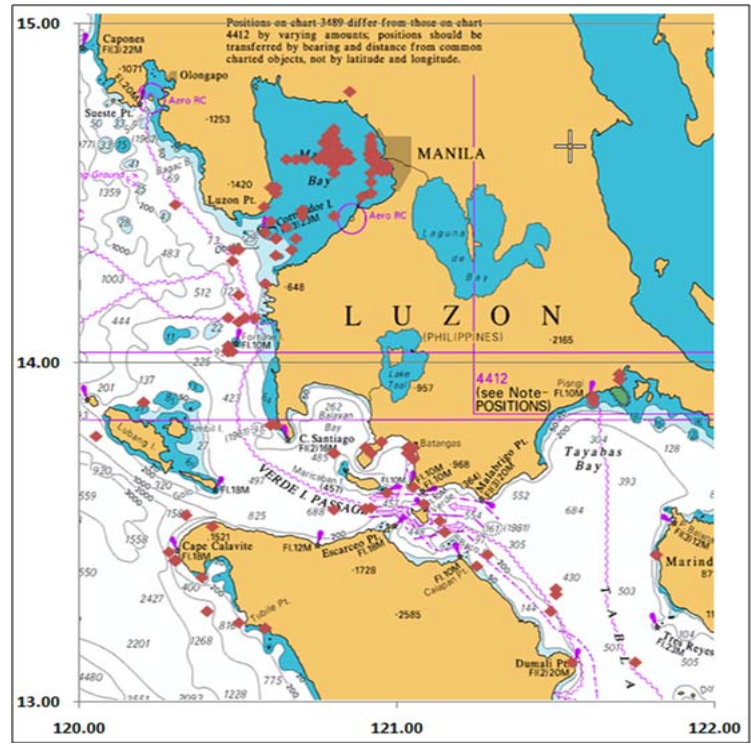

Fig. 12 Manila Bay (NCR) and Southern Tagalog

Fig. 12 highlights the crowded red dots in the area of Manila Bay and the southern port of Batangas Bay and adjacent seas where the approximate locations of most of the major accidents (266, Fig 10) occurred. The approximate geographical locations of these accidents were sourced from PPA, Marina, PCG and various news clippings, located through the British Admiralty (BA) charts covering the area of accident and then plotted onto the electronic charts covering the areas concerned.

Fig. 13 plots the 33 accidents that occurred in the southern parts of the country covering the Mindanao archipelago and the Jolo group of islands.

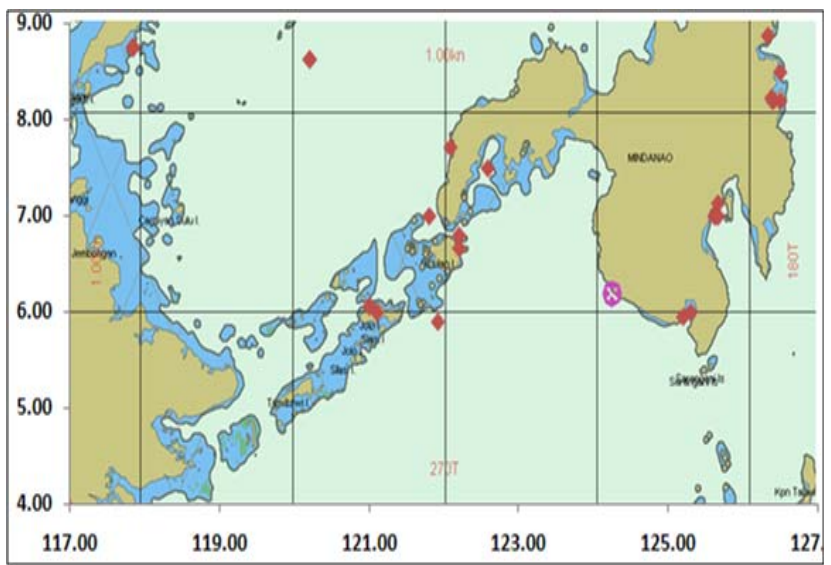

Fig. 13 Mindanao and Sulu Islands region

\subsection{The human element factor (Effect on mariners)}

With all these tragedies with massive loss of human lives, and the least emphasis on the effect to the marine environment, it is the seafarer that bears the brunt of the criticisms and public outrage. The country has been more emphatic in deploying its seafarers on international waters than ply the domestic lanes. This is mainly due to several imbalance factors: the financial gain is the most glaring but the security of the job and their families' future have the most impact on these personal and professional decisions. Other factor like the criminalization of seafarer practiced in other countries is now being advanced by some lawmakers in the local jurisprudence.

However, in the local maritime environment hostile treatment were given to those who had made mistakes or had been unlucky. In the investigation looking for the first possible cause of the vessel's mishaps after a tragedy, usually cited was the failure of the master of the ship to exercise extraordinary diligence and good seamanship thereby committing an error of judgment that brought the hapless vessels in harm's way. The master was often ill-treated and disadvantaged where the probability of harassment and arrest were subjected to him for crimes which he was just a part of. At this time, the master should know where he stands in jurisdictional law. He should have the information at hand to know when and where and by whom he might be lawfully subjected. Unfortunately or fortunately for him, often he ended up the casualty himself, dead or missing, and this made him a very good and convenient scapegoat by the very people who are keen more on protecting their self-interests rather than observing their social responsibilities and serving their loyal employees. Handling 
an old, dilapidated, under-manned with incompetent crews, and ill-equipped vessels, the master and his crews were not situationally aware and ready in times of crisis. Their sub-standard environment onboard, the shipping company's lopsided policies and the mainly toothless national shipping regulations all add up to low morale and complacency attitudes that are all contributory to the occurrence of maritime disasters.

How would we expect or, at least aspire, to be seaworthy these domestic sea-crafts when our shipping environment is working with a minimum safety-conscious attitude and a more profit-driven market mindset? Where our domestic seafarers are working in a thankless, less-friendly and least safety-conscious ergonomics?

\subsection{The analysis of their causes}

The country's archipelagic and porous setting make the domestic shipping industry lucrative for big businesses and a necessity for common peoples living in far-flung islands to travel their goods and produce, to go about and for work where they find mostly in big cities. However, horrendous accidents occurred that cost human lives, damage to properties and endangering the environment. The country's domestic shipping industry has been regarded as inefficient largely because of toothless policies; port facilities far below world-class standards with some ports still under- de $^{-}$ veloped and inadequate waterways; ineffective vessel traffic management; poor maintenance of vessels; profit mind-set of shipping companies; and unsafe and complacent attitudes of all parties on the observation of safety and security policies and regulations. Passenger vessels are still sailing not only with insufficient life preserving aids, but with manifests willfully showing incorrect details. Official data col- $^{-}$ lected differ from actual number of casualties (dead and/or missing) because most of the ships lost and/or capsized were overloaded. The sinking of the Super-Ferry 14 showed the vulnerability of the maritime transport to terror attacks and the need for strict security measures.

Personnel manning the domestic fleet also were found to having willfully disobey traffic routes and VTMS people nonchalantly allowed such behavior. Collisions have the highest of casualties which was attributed to poor navigation, non-observance of the rules of the road and lack of prudent seamanship.

Infrastructures were likewise deficient. The minimum number of lighthouses installed are mostly non-operational and dredging of the ports' approaches has barely been carried out. Weather bureau was blamed for gross negligence, and inaccuracies in its forecasts that caused ships to sink. Results of BMI investigation of mostly the sinking and grounding incidents were due to bad weather.

\section{Brief summary of recent local legislations and latest IMO Resolutions}

Table 4 below lists a few of the recent legislation and policies addressing the concerns of the maritime situations in the country that may mitigate and avert the occurrences of tragedies.

Table 4 Notable local maritime regulations

\begin{tabular}{l} 
Republic Act 8544 (February 24, 1998) An Act Regulating the Practice of \\
the Merchant Marine Profession in the Philippines \\
\hline PPA Administrative Order No.1-2008. Guidelines Implementing the \\
Vessel Traffic Management System at the Port of Batangas. \\
Philippine Coast Guard Memorandum Circular No.03-03 (09 July 2003) \\
Routeing System at Corregidor Island Passages (North and South). \\
PPA Administrative Order No.3-2006. Guidelines Implementing the \\
Vessel Traffic Management System at the Port District of Manila. \\
Channels). pages 1-9 with attached chart. \\
MARINA Circular No. 2009-25 Rules and Regulations on the Approval \\
of Lifejackets and Lifebuoys for Ships Engaged in Domestic Shipping. \\
MARINA Circular No. 2009-23 Rules in the Grant of Missionary Route \\
Operator Status for RO-RO and Similar Type of Ships \\
MARINA Circular No. 2009-18 Rules Reiterating the Mandatory \\
P200,000.00 Compulsory Passenger Insurance Coverage to Manifested \\
Passengers; Indemnity of P200,000.00 per Un-manifested Passenger to be \\
Shouldered by the Shipowner/Operator P50,000.00 Monetary Assistance \\
to Each Survivor Over and Above Medical, Hospitalization and other \\
Incidental Expenses; and, Imposing Penalties for Violation thereof.
\end{tabular}

In the last IMO Diplomatic Conference held in Manila, it had passed important resolutions to amend the SCTW. Table 5 shows the most important of these resolutions:

Table 5 Latest IMO ammendments on STCW resolutions in regards to seafarers competency

\begin{tabular}{|c|l|}
\hline Res. 6 & $\begin{array}{l}\text { Standards of training and certification and ships' manning } \\
\text { levels; }\end{array}$ \\
\hline Res. 7 & $\begin{array}{l}\text { Promotion of technical knowledge, skills and professionalism of } \\
\text { seafarers, and }\end{array}$ \\
\hline Res. 8 & $\begin{array}{l}\text { Development of guidelines to implement international standards } \\
\text { of medical fitness for seafarers. }\end{array}$ \\
\hline
\end{tabular}

These resolutions, as amended, shall ensure that seafarers have more protection and support in the practice of their profession. Further, the last Conference adopted two landmark resolutions, Table 6 , recognizing the contribution seafarers from all over the world make to international seaborne trade, the world economy and civil society as a 
whole.

Table 6 IMO landmark resolutions recognizing the contribution seafarers

\begin{tabular}{|c|l|}
\hline Res.18 & $\begin{array}{l}\text { Year of the Seafarer set the guidelines on the fair treatment } \\
\text { of seafarers in the event of a maritime accident; on provision } \\
\text { of financial security in case of abandonment of seafarers; and } \\
\text { on shipowners' responsibilities in respect of contractual } \\
\text { claims for personal injury to, or death of, seafarers. }\end{array}$ \\
\hline Res.19 & $\begin{array}{l}\text { Day of the Seafarer which recognizes the considerable risks } \\
\text { seafarers shoulder in the execution of their daily tasks and } \\
\text { duties in an often hostile environment, and the deprivations to } \\
\text { which seafarers are subject through spending long periods of } \\
\text { their professional life at sea away from their families and } \\
\text { friends. }\end{array}$ \\
\hline
\end{tabular}

In 2006, the ILO adopted the Maritime Labour Convention (MLC). This legislation should consolidates and updates more than 65 international labor standards while ensuring the high level of minimum standards for working and living conditions for seafarers - a valuable contribution to the fair treatment of seafarers.

\section{Conclusion and Recommendation}

This paper examined the various accidents on the domestic shipping that involved mostly domestic ships. These tragedies impacted negatively to the national and international reputation of the country. For a nation which provides such a large percentage of crew onboard foreign ships, these brought national shame and a collective guilt.

Domestic shipping is also beginning to recognize that it needs talented and committed people to navigate the $\mathrm{do}^{-}$ mestic waters and will have to compete with the global labor market. It is the 'people challenge' that must command most attention to cultivate a safety mentality and practices to mitigate the occurrence of maritime tragedies.

However, preventative and pro-active actions should be observed by the local authorities and implement the toothless regulations in exchange for a safer seas and friendly maritime environment.

To find solutions to these problems would not be as easy as it would seem. Changes are hard-put for peoples whose lives evolve in these situations where it had already been ingrained and accepted as traditions and customs of society. However, this paper would offer recommendations as disparate these problems may seem.

- Strict implementation of sound maritime rules concerning safety and security in par with international standards and norms.
- Educate and train all parties of the international maritime standards on safety and security. These include ship and shore based personnel together with the officials who administer and police the shores and docks up to the doors of big businesses and public offices.

- Upgrade the maritime safety infrastructures like the nav-aids, lighthouses, vessel monitoring services and systems, other maritime ancillary services like the weather bureaus.

- Upgrade the ships, their maintenance and logistical necessities. Dilapidated and rust-bucket ships should be phased out of service.

- Judicious handling of maritime cases. It has been accepted as natural to have cases lodged in the courts for years or even decades without being resolved or found closure. This will send out message to all concerned that non-observance of due diligence, good seamanship practices, plain common sense and the sound maritime laws will be dealt with accordingly.

\section{References}

[1] Department of Transportation and Communication (2010), About OTS, Office of Transport Security, http://www.ots.gov.ph

[2] IMO DipCon (2010), International Convention on STCW for Seafarers, 1978. Agenda item 10 STCW/CONF.2/DC/4. Original: English Adoption of the Final Act and any Instruments, Resolutions and Recommendations Resulting from the Work of the Conference. pages 18, 19,20.

[3] Inquirer Archives (2010), Sulpicio Lines Inc. Sea Accidents. Source: LLOYD'S MIU,

[4] Manila VTMS (2010), Interview with MICT tower personnel 1320-1400H, 14th July 2010.

[5] MARINA (2010), AO No.13-10, Creation of Maritime Crisis Management Committee and Institutionalization of Actions/Procedures Guidelines to Immediately Deal with Maritime Accidents/Incidents, pages 1-4

[6] Maritime Industry Authority (2010), Memo Circulars and Republic Acts, www.marina.gov.ph/policies/

[7] Philippine Atmospheric, Geophysical and Astronomical Services Administration (PAGASA) (2010), Annual Report. pages $4-5$

[8] Philippine Coast Guard (2003), PCG Memorandum Circular No.03-03. Routeing System at Corregidor Island Passages (North and South Channels), pages 1-9 with attached charts. 
[9] Philippine Coast Guard (2010), Major Maritime Accidents - 2000-2009, pages 1-6

[10] Philippine Daily Inquirer (2009), List of deadliest ferry accidents in RP, (First Posted 03:49:00 09/07/2009).

[11] Philippine Ports Authority (2006), PPA AO No.3, Guidelines Implementing the Vessel Traffic Management System at the Port District of Manila, pages 1-4.

[12] Philippine Ports Authority (2008), PPA AO No.1, Guidelines Implementing the Vessel Traffic Management System at the Port of Batangas, pages 1-4

[13] Philippine Ports Authority (2009), PPA Annual Report, pages $6,23-26$

[14] Tropical Cylclone Tracks (2009), The 2009 Philippine Tropical Cyclone Summary, http://www.typhoon2000.ph/.

Received 28 March 2011

Revised 24 June 2011

Accepted 27 June 2011 